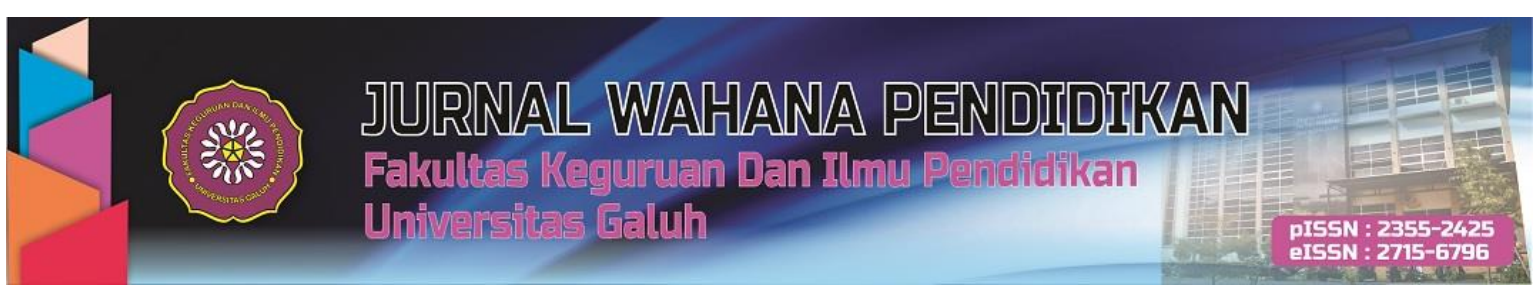

https://jurnal.unigal.ac.id/index.php/jwp

\title{
PENINGKATAN KEMAMPUAN BERBICARA SISWA KELAS IV SD NEGERI 2 SUKAMAJU KOTA TASIKMALAYA MELALUI PENGGUNAAN MEDIA GAMBAR
}

\author{
Cucu Damanix \\ SD Negeri 2 Sukamaju JI. Parakanhonje No.83, Sukamajukaler, Kec. Indihiang, Tasikmalaya, Indonesia \\ Email: nasaruana@gmail.com
}

\section{ABSTRACT}

This study aims to determine the speaking ability of fourth grade students of SD Negeri 2 Sukamaju Kota Tasikmalaya through the use of image media in learning. This research was conducted in the 2019/2020 school year with a sample of 29 students. The research method is classroom action research. Data collection through interviews, observation sheets, and tests. Based on the results of the study, there were significant changes in the students' speaking ability in each cycle. In the pre-cycle observation, only 3 students or $10.34 \%$ were categorized as quite fluent and proficient, daring to speak. Furthermore, in cycle I, 6 students or $20.68 \%$ were categorized as almost fluent and almost brave with sufficient voices. In the second cycle, $34.48 \%$ of the 10 students were categorized as almost fluent and brave with loud enough voices. At the end of the third cycle there were 15 students or $51.72 \%$ in the good category, 10 students or $34.48 \%$ in the enough category and 4 students or $13.79 \%$ in the poor category. The results showed that learning using image media helped and attracted students to speak in Indonesian which was applied by storytelling so as to improve students speaking skills.

Keywords: speaking skills, image media, Indonesian

\section{ABSTRAK}

Penelitian ini bertujuan mengetahui kemampuan berbicara siswa kelas IV SD Negeri 2 Sukamaju Kota Tasikmalaya melalui penggunaan media gambar dalam pembelajaran. Penelitian ini dilaksanakan pada tahun pelajaran 2019/2020 dengan sampel sebanyak 29 orang siswa. Metode penelitian dengan penelitian tindakan kelas. Pengumpulan data melalui wawancara, lembar observasi, dan tes. Berdasarkan hasil penelitian terdapat perubahan signifikan kemampuan siswa dalam berbicara pada tiap siklus. Pada observasi prasiklus hanya 3 orang siswa atau $10,34 \%$ yang termasuk kategori cukup lancar dan cakap, berani untuk berbicara. Selanjutnya pada siklus I, 6 orang siswa atau 20,68\% termasuk kategori hampir lancar dan hampir berani dengan suara cukup. Pada siklus II, 10 orang siswa 34,48\% yang termasuk kategori hampir lancar dan berani dengan suara cukup keras. Diakhir siklus III mencapai 15 orang siswa atau 51,72\% yang termasuk kategori baik, 10 orang siswa atau 34,48\% kategori cukup dan 4 orang siswa atau 13,79\% dalam kategori kurang. Hasil penelitian menunjukkan pembelajaran dengan penggunaan media gambar membantu dan menarik minat siswa untuk berbicara dalam Bahasa Indonesia yang diaplikasikan dengan bercerita sehingga dapat meningkatkan kemampuan berbicara siswa.

Kata Kunci: berbicara, media gambar, Bahasa Indonesia

Cara sitasi:

Damanix, C. (2020). Peningkatan Kemampuan Berbicara Siswa Kelas IV SD Negeri 2 Sukamaju Kota Tasikmalaya Melalui Penggunaan Media Gambar. Jurnal Wahana Pendidikan, 8 (1), 27-42. 


\section{PENDAHULUAN}

Bahasa merupakan sarana untuk saling berkomunikasi, saling berbagi pengalaman untuk meningkatkan kapasitas intelektual. Ini berarti bahwa setiap warga negara dituntut terampil menggunakan Bahasa Indonesia. Sebagaimana tercantum dalam Undang-undang Dasar 1945 Bab XV pasal 36 yang berbunyi, "Bahasa negara ialah Bahasa Indonesia. Sesuai dengan kedudukan Bahasa Indonesia sebagai bahasa negara dalam Undang-undang Republik Indonesia No. 20 Tahun 2003 tentang Sistem Pendidikan Nasional Bab VIII Pasal 33 telah ditetapkan bahwa: "Bahasa pengantar dalam pendidikan nasional adalah Bahasa Indonesia.

Sebagian besar anak Indonesia lahir dan mulai kehidupannya sebagai anak daerah. Mereka berkembang dan belajar mengenali sekitarnya melalui bahasa daerah. Melalui bahasa daerah itu mereka belajar berprilaku dan bersikap sebagai insan daerah disekitarnya. Namun, disamping itu mereka juga anak Indonesia yang harus tumbuh menjadi warga negara Indonesia yang baik. Bahasa Indonesia mempunyai peranan penting dalam pendidikan. Melalui pembelajaran Bahasa Indonesia guru harus dapat menjadikan anak-anak daerah itu menjadi anak-anak Indonesia yang berfikir, bersikap dan berperilaku sebagai anak Indonesia yang baik. Disamping itu Bahasa Indonesia diperlukan sebagai dasar untuk mempelajari materi pembelajaran lainnya.

Didalam Kurikulum diamanatkan bahwa Bahasa Indonesia dipahami bukan dari pengucapan saja, tetapi Bahasa Indonesia mempunyai empat aspek yang harus dikaji, yaitu : aspek menyimak, berbicara, membaca dan menulis. Dari aspek-aspek tersebut di atas yang dipelajari dalam pengajaran Bahasa Indonesia adalah aspek berbicara. Aspek berbicara sangat penting karena dengan berbicara siswa dapat berinteraksi dan bersosialisasi untuk memenuhi kebutuhan hidupnya. Berbicara merupakan suatu penyampaian maksud (ide, pikiran dan isi hati) seseorang kepada orang lain dengan menggunakan bahasa lisan, sehingga maksud tersebut dapat dipahami oleh orang lain (Ibda dan Ahmadi, 2018).

Kemampuan berbicara merupakan salah satu kemampuan berbahasa yang perlu dimiliki oleh seseorang. Kemampuan ini bukanlah kemampuan yang diwariskan secara turun temurun, walaupun pada dasarnya secara alamiah manusia dapat berbicara. Namun kemampuan berbicara secara pada situasi tertentu atau secara formal misalnya memerlukan latihan dan pengarahan atau bimbingan yang intensif (Setyonegoro, 2013). Kegiatan berbicara secara formal misalnya berbicara dalam kelas, berdiskusi, seminar, berceramah, berpidato dan sebagainya.

Mata pelajaran bahasa dan sastra Indonesia adalah program untuk mengembangkan kemampuan, keterampilan, berbahasa dan sikap positif terhadap Bahasa Indonesia. Pembinaan kemampuan berbicara dalam situasi formal biasanya dilakukan dalam proses belajar mengajar siswa di sekolah. Tercapainya kemampuan berbicara siswa tidak lepas dari peran guru dalam interaksinya siswa melalui pembelajaran di kelas. "Berbicara adalah kemampuan mengucapkan bunyi-bunyi artikulasi atau kata-kata untuk mengekspresikan, menyatukan serta menyampaikan pikiran, gagasan dan perasaan" (Tarigan, 1997). Berdasarkan pendapat tersebut berbicara itu lebih dari pada sekedar mengucapkan bunyi-bunyi atau kata-kata saja, melainkan suatu alat untuk mengkomunikasikan gagasan-gagasan yang disusun serta dikembangkan sesuai dengan kebutuhan-kebutuhan pendengar atau penyimak.

Proses penyampaian pesan melalui bahasa hendaknya diungkapkan sesuai makna yang akan dikehendaki. Pada dasarnya kemampuan berbicara pada siswa Sekolah Dasar dimulai sejak dari masa Kanak-kanak, proses pemerolehannya pun ditentukan oleh beberapa aspek. Aspek-aspek itu antara lain aspek kematangan biologis, kognitif dan interaksi sosial, proses perkembangan dan kemampuan fisik dan sosial mengakibatkan siswa semakin berkembang.

Pemerolehan kebahasaan siswa dalam kehidupan sehari-hari khususnya Bahasa Indonesia dalam aspek berbicara sangat terbatas. Ini berdasarkan pengamatan di kelas IV SD Negeri 2 Sukamaju Kecamatan Indihiang Kota Tasikmalaya sebagian besar siswa kesulitan untuk mengungkapkan kata-kata dalam Bahasa Indonesia. Misalnya ada siswa yang sulit untuk diajak 
berbicara, ada siswa yang pandai dalam berbagai mata pelajaran tapi sulit untuk menggunakan bahasa lisan, ada pula siswa yang banyak berbicara tapi pembicaraannya tidak terarah.

Faktor-faktor yang menyebabkan siswa mendapat kesulitan dalam berbicara, diantaranya : 1) Siswa kurang menguasai Bahasa Indonesia yang baik sehingga anak malu untuk berbicara, 2) Siswa kurang fasih dalam melafalkan kata-kata Bahasa Indonesia, 3) Penguasaan kosa kata siswa terbatas, 4) Siswa kurang mampu menyusun struktur kalimat yang baik, 5) Siswa kurang memahami dan kurang bisa menangkap topik yang disajikan guru untuk bercerita.

Kemampuan siswa dalam berbicara sangat bergantung kepada proses belajar mengajar yang dirancang guru. Oleh sebab itu, dalam proses belajar mengajar harus diciptakan suasana yang mampu memberi motivasi yang tinggi sehingga dapat membangkitkan gairah siswa dalam interaksi belajarnya. Timbulnya kegairahan siswa dalam belajarnya, menurut kreatiftas guru dalam menyajikan materi pembelajaran. Pemakaian alat peraga dalam pengajaran dapat membantu perkembangan kreativitas guru dan siswa (Arsyad, 2007). Dengan demikian guru dapat memikirkan berbagai cara untuk menyajikan pelajaran dengan menggunakan alat peraga sehingga lebih menarik siswa minat. Media pengajaran dapat menjadi salah satu fasilitator bagi guru untuk membantu murid-muridnya dalam mendapatkan berbagai kompetensi pengajaran.

Salah satu alternatif yang dapat digunakan untuk menumbuh kembangkan kemampuan berbicara siswa adalah melalui penggunaan media gambar. Media gambar membawa dan membangkitkan rasa senang dan gembira bagi siswa dan memperbaharui semangat mereka, membantu memantapkan pengetahuan pada benak para siswa serta menghidupkan pelajaran. Gambar-gambar yang diberikan kepada siswa harus berisi suatu aktifitas dan bermakna, melalui gambar diharapkan siswa mampu mengungkapkan ide, pendapat, melatih percaya diri dan dapat mengembangkan fantasi atau imajinasi siswa (Suyatno et.al, 2017). Berdasarkan latar belakang tersebut penelitian ini bertujuan untuk mengetahui kemampuan dan keterampilan berbicara siswa kelas IV SD Negeri 2 Sukamaju Kota Tasikmalaya melalui penggunaan media gambar dalam pembelajaran.

\section{METODE PENELITIAN}

. Metode yang digunakan dalam penelitian ini adalah metode Penelitian Tindakan Kelas (PTK). Alasan penulis menggunakan metode Penelitian Tindakan Kelas, karena metode ini merupakan suatu cara dalam melaksanakan penelitian yang sistematis berdasarkan kegiatan pembelajaran di kelas, dalam usaha memperbaiki praktek-praktek pendidikan dengan melakukan tindakan praktis melalui refleksi dari tindakan tersebut yang bertujuan untuk meningkatkan mutu pendidikan.

Model Penelitian Tindakan Kelas yang digunakan dalam penelitian ini adalah Model Kemmis dan Mc Taggart, karena model Penelitian Tindakan Kelas ini mudah dipahami dan sesuai untuk dimanfaatkan oleh peneliti. Menurut Kemmis dan Mc Taggart tiap siklus terdiri dari empat langkah yang harus dilaksanakan, yaitu: (1) Perencanaan (planning), (2) Tindakan (action), (3) Pengamatan (observing), (4) refleksi (reflecting) (Kemmis \& McTaggart, 1988). Pada penelitian ini peneliti merencanakan tiga siklus. Desain PTK yang dilakukan seperti pada Gambar 1 berikut.

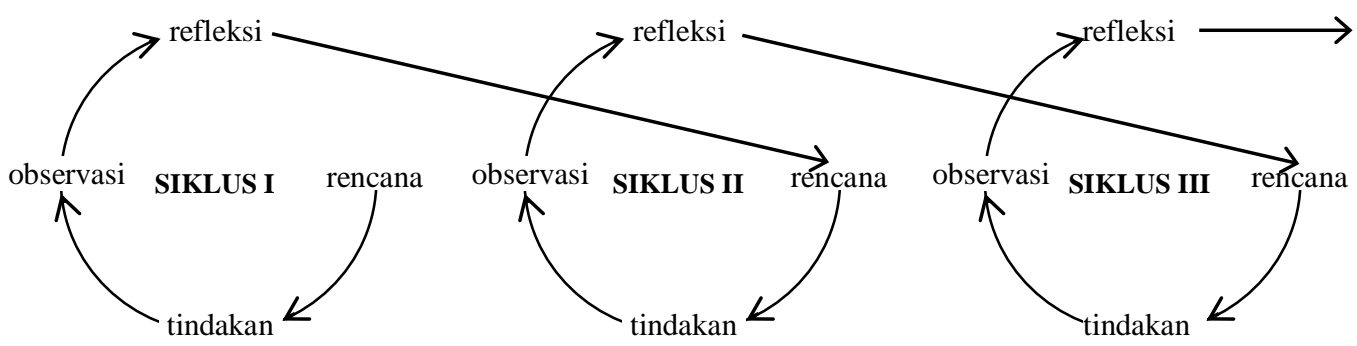

Gambar 1. Desain model PTK Kemmis dan Mc Taggart

Penelitian ini bertujuan untuk memperoleh data yang akurat tentang cara mengefektifkan pelaksanaan pembelajaran dalam upaya meningkatan kemampuan berbicara dengan menggunakan 
media gambar pada siswa kelas IV SD Negeri 2 Sukamaju Kecamatan Indihiang Kota Tasikmalaya Tahun Pelajaran 2019/2020. Sampel yang digunakan pada Penelitian Tindakan Kelas ini adalah sebanyak 29 orang siswa.

Penelitian Tindakan Kelas yang sesuai dengan Kemmis dan Mc Taggart merupakan model PTK yang sangat mudah untuk diterapkan. Hal ini kemudahan yang dilakukan dan tingkat keberhasilan serta tahapan demi tahapan mudah dilaksanakan. Mulai dari bentuk perencanaan, pelaksaan penelitian, observasi dan refleksi merupakan tahapan-tahapan yang sangat tepat peneliti mengadakan tahapan-tahapan penelitian tersebut dalam upaya meningkatkan hasil belajar siswa dan kinerja guru dalam melakukan PTK. Alur penelitian yang dilakukan seperti dalam Gambar 2. berikut.

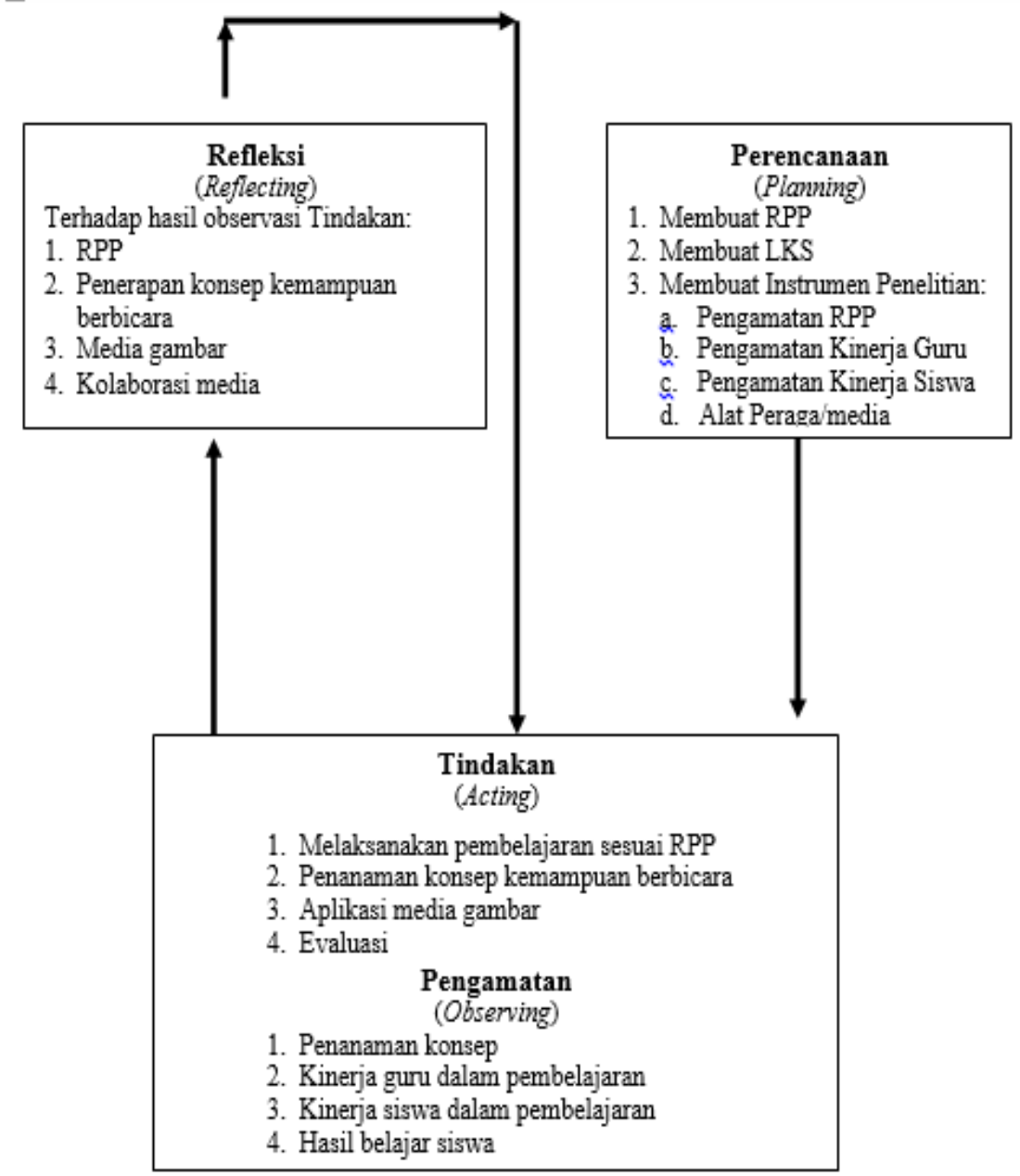

Gambar 2. Diagram Alur Penelitian Tindakan Kelas

Fokus penelitian pada tiap siklus adalah pembelajaran yang mengarahkan pembelajaran upaya meningkatan kemampuan berbicara dengan menggunakan media gambar pada siswa kelas IV SD Negeri 2 Sukamaju Kecamatan Indihiang Kota Tasikmalaya Tahun Pelajaran 2019/2020.

\section{a. Perencanaan}

Rencana tindakan selanjutnya adalah penyusunan rencana pembelajaran, mulai menetap dan memilih jenis gambar yang sesuai dengan siswa kelas IV yaitu menggunakan beberapa buku sumber, situasi atau kondisi kelas yang akan digunakan serta mempersiapkan instrumen-instrumen sebagai alat pengumpul data. Setelah semua rencana awal tersusun rapi selanjutnya merencanakan langkah-langkah pembelajaran yang dilaksanakan tahap demi tahap yaitu mulai dari kegiatan awal, kegiatan inti dan kegiatan akhir. Rencana pelaksanaan PTK ini sebanyak tiga siklus.

b. Pelaksanaan Tindakan dan Observasi 
Pelaksanaan proses pembelajaran pada siklus pertama, terdiri atas dua kali pertemuan masing-masing pertemuan $2 \times 35$ menit. Siklus pertama dilaksanakan hari Selasa tanggal 12 November 2019, pertemuan pertama mulai pukul 07.30-08.40 WIB, pertemuan kedua dimulai pukul 08.40-09.50 WIB, dengan jumlah siswa 29 orang proses pelaksanaan pembelajaran dengan cara individual, hal ini dimungkinkan lebih efektif untuk mengkondisikan siswanya.

Rencana pembelajaran pada siklus II, terdiri dari dua kali pertemuan dengan alokasi waktu tiap pertemuan $2 \times 35$ menit. Pelaksanaan tindakan siklus II ini dilaksanakan hari Selasa tanggal 19 November 2019, pertemuan I dimulai pukul 07.40-08.40 dan pertemuan II dimulai pukul 08.40-09.50 dengan jumlah siswa masih tetap 29 orang. Pada siklus II ini pembelajaran dilaksanakan secara berkelompok maksudnya agar suasananya lebih menyenangkan. Dari jumlah siswa 29 orang tersebut dibagi menjadi enam kelompok, lima kelompok terdiri dari lima orang dan satu kelompok terdiri dari 4 orang.

Rancangan pengajaran pada siklus III ini terdiri dari dua kali pertemuan, dengan alokasi waktu tiap pertemuan $2 \times 35$ menit. Rencana kegiatan pada siklus IV ini adalah guru membuat media gambar sendiri dengan sejumlah siswa 29 orang dan tentunya gambar tersebut yang mudah dipahami oleh siswa kelas IV serta bermacam-macam jenisnya, seperti alat permainan, kendaraan, hewan, buga, benda-benda langit dan lain-lain. Gambar yang dipilih siswa dapat diketahui dengan jelas. Pengamatan sebagai bahan motivasi akan lebih ditampakkan pada siklus ini.

c. Analisis dan Refleksi

Analisis dan refleksi ini dilakukan setelah pembelajaran berlangsung kemudian bersamasama dengan rekan observasi berdiskusi tentang isi pembelajaran yang baru saja dilaksanakan. Berdasarkan hasil pengamatan pada tampilan kegiatan belajar mengajar pada tiap siklus yang diperhatikan adalah beberapa catatan hasil diskusi yaitu diantaranya situasi kelas, pelaksanaan bercerita di depan kelas dan keberanian siswa ketika berada di depan kelas. Dari ketiga hal tersebut perlu mendapat perhatian pada siklus berikutnya, bertujuan agar kemampuan berbicara siswa lebih optimal dan siswa lebih sering mengikuti pelajaran berbicara.

\section{HASIL DAN PEMBAHASAN}

\section{Pelaksanaan Tindakan Siklus I}

Tujuan dilaksanakannya tindakan pertama adalah untuk menindaklanjuti hasil dari refleksi pada pra siklus, maka ditetapkan untuk mengatasi kesulitan siswa dalam berbicara akan menggunakan media gambar sebagai media pembelajaran penggunaan media gambar ini diharapkan akan membantu memotivasi timbulnya ide (gagasan) siswa dalam bercerita dan menambah wawasan dalam pembendaharaan kosa kata Bahasa Indonesia untuk meningkatkan kemampuan berbicara siswa.

Atas dasar hasil analisis observasi awal, untuk langkah berikutnya yang dilakukan adalah mengadakan diskusi dengan teman sejawat sebagai observer. Adapun yang didiskusikan membahas tentang langkah apa yang harus ditempuh dalam pelaksanaan pembelajaran nanti.

\section{a. Perencanaan}

Perencanaan yang dilakukan pada tahap I adalah penyusunan rencana pembelajaran, mulai menetap dan memilih jenis gambar yang sesuai dengan siswa kelas IV yaitu menggunakan beberapa buku sumber, situasi atau kondisi kelas yang akan digunakan serta mempersiapkan instrumen-instrumen sebagai alat pengumpul data. Rencana pengajaran pada siklus pertama ini terdiri dari dua kali petemuan, dengan alokasi waktu tiap pertemuan $2 \times 35$ menit. Rencana pengajaran ini berpedoman pada kurikulum.

b. Pelaksanaan Tindakan dan Observasi

Pelaksanaan proses pembelajaran pada siklus pertama, terdiri atas dua kali pertemuan masing-masing pertemuan $2 \times 35$ menit. Proses pelaksanaan pembelajaran dengan cara individual, hal ini dimungkinkan lebih efektif untuk mengkondisikan siswanya. Langkah pertama dalam pembelajaran guru membuka pelajaran (apersepsi), lalu menjelaskan langkah-langkah dasar dalam 
bercerita dan menjelaskan pula hal-hal yang harus diperhatikan dalam menggunakan media gambar. Langkah selanjutnya melihat situasi dan kondisi kelas sudah tampak tertib, lalu guru membagikan gambar seri yang berbeda untuk diamati dan ceritakan isinya. Kemudian guru menjelaskan kegiatan yang harus dilaksanakan siswa dengan gambarnya.

Hasil pengamatan pada siklus pertama siswa ribut dan situasi kelas menjadi ramai membicarakan gambar tersebut mereka saling melihat dan membandingkan dengan gambar teman yang lainnya. Kemudian ada siswa yang bertanya kepada guru karena tidak paham tentang tugas yang harus dikerjakan, guru kembali menjelaskan pertanyaan-pertanyaan dari siswa.

Siswa kembali sibuk dan ramai, dan lama-lama mereka tampak kebingungan, guru berkeliling menghampiri siswa dan bertanya tentang kesulitan yang dialami. Rupanya siswa ramai dan bertanya tentang kesulitan yang dialami. Rupanya siswa ramai menanggapi gambar dengan bahasa sehari-hari (bahasa Sunda). Ketika disuruh bercerita dalam Bahasa Indonesia mereka keberatan sambil menggelengkan kepala, untuk memberikan dorongan kepada siswa untuk bercerita meskipun hanya beberapa kata saja, guru memotivasi siswa agar berani kedepan untuk bercerita. Ada salah seorang siswa yang meminta agar ditulis dulu ceritanya baru dibacakan di depan.

Maka siswa pun kembali ramai, tapi sebagian siswa ada yang tidak peduli mereka hanya membicarakan tentang gambar bukannya menyusun cerita. Setelah semua siswa selesai, lalu hasilnya dikumpulkan, guru memanggil siswa untuk membacakan cerita di depan. Siswa yang lain memperhatikan dengan baik. Guru memberikan nilai pada lembar penilaian dan langsung mengomentari tiap cerita yang cibacakan siswa, semua itu terjadi pada pertemuan pertama.

Pada akhir pertemuan kedua diperoleh hasil dari penilaian keterampilan sebagai berikut :

1) Siswa yang sudah hampir lancar berbicara penggunaan lapal dan intonasi yang cukup, juga tampak cukup memiliki keberanian, dengan suara yang cukup, juga tampak cukup memiliki keberanian, dengan suara yang cukup keras sebanyak 6 orang atau sekitar $20,68 \%$.

2) Siswa yang sudah hampir lancar berbicara tetapi lapal dan intonasi mendatar dan terbata-bata seperti membaca, tapi cukup berani sebanyak 12 orang atau sekitar $41,37 \%$.

3) Siswa yang masih ragu-ragu tapi sudah bisa bercerita walaupun hanya beberapa kata, cukup berani dan suara pelan sebanyak 11 orang atau sekitar $37,93 \%$.

Observasi kemampuan berbicara siswa dapat disimak pada Tabel 1 dan pemerolehan skor kemampuan berbicara pada siswa siklus I pada Tabel 2 .

Tabel 1.

Observasi Kemampuan Berbicara Siswa Pada Siklus I

\begin{tabular}{cll}
\hline No & \multicolumn{1}{c}{ Nama } & \multicolumn{1}{c}{ Deskripsi Kemampuan } \\
\hline 1 & Asiah Amini & Cukup lancar, lapal dan intonasi cukup, kuranng berani. \\
2 & Abdul Holik & Hampir lancar, lapal dan intonasi cukup, cukup berani. \\
3 & Badra Tamami & Cukup lancar, lapal dan intonasi cukup, cukup berani. \\
4 & Diki Hermawan & Hampir lancar, lapal dan intonasi cukup, cukup berani. \\
5 & Indra Karso & Tidak lancar, tidak berani. \\
6 & M. Sopyan & Cukup lancar, lapal dan intonasi cukup, kurang berani. \\
7 & M. Abdul Rojak & Cukup lancar, lapal dan intonasi cukup, cukup berani. \\
8 & M. Dadang Suhendar & Cukup lancar, lapal dan intonasi cukup, kurang berani. \\
9 & M. Jauhari AJ. & Cukup lancar, lapal dan intonasi cukup, cukup berani. \\
10 & Nuraeni & Kurang lancar, lapal dan intonasi cukup, kurang berani. \\
11 & Nurlaela & Cukup lancar, lapal dan intonasi cukup, cukup berani. \\
12 & Nadiya & Cukup lancar, lapal dan intonasi cukup, cukup berani. \\
13 & Putri Aprilianti & Cukup lancar, lapal dan intonasi cukup, cukup berani. \\
14 & Popi Hikmah F. & Cukup lancar, lapal dan intonasi cukup, cukup berani. \\
15 & Riki Firdaus & Cukup lancar, lapal dan intonasi cukup, cukup berani. \\
16 & Rouf Firmansyah & Cukup lancar, lapal dan intonasi cukup, cukup berani. \\
17 & Sunardi & Hampir lancar, lapal dan intonasi cukup, cukup berani. \\
18 & Sarmidi & Hampir lancar, lapal dan intonasi cukup, cukup berani. \\
19 & Suheni & Hampir lancar, lapal dan intonasi cukup, cukup berani. \\
\hline
\end{tabular}




\begin{tabular}{lll}
\hline 20 & Siti Diana & Kurang lancar, tidak berani. \\
21 & Siti Hikmah & Cukup lancar, lapal dan intonasi cukup, cukup berani. \\
22 & Siti Rosidah & Cukup lancar, lapal dan intonasi cukup, cukup berani. \\
23 & Saudatul Faridah & Kurang lancar, tidak berani. \\
24 & Azizah & Cukup lancar, lapal dan intonasi cukup, cukup berani. \\
25 & Julaeha & Kurang lancar, lapal dan intonasi cukup, kurang berani. \\
26 & Dila Andrianti & Kurang lancar, lapal dan intonasi cukup, kurang berani. \\
27 & Suminah & Tidak lancar, tidak berani. \\
28 & Rohanah & Kurang lancar, lapal dan intonasi cukup, kurang berani. \\
29 & Irwansyah & Cukup lancar, lapal dan intonasi cukup, cukup berani. \\
\hline
\end{tabular}

Tabel 2.

Pemerolehan Skor Kemampuan Berbicara pada Siswa Siklus I

\begin{tabular}{|c|c|c|c|c|c|c|c|c|}
\hline No & Nama Siswa & $\begin{array}{c}\text { Lapal } \\
\text { dan } \\
\text { Intonasi }\end{array}$ & $\begin{array}{c}\text { Pengua } \\
\text { Saan } \\
\text { Kosa kata }\end{array}$ & $\begin{array}{l}\text { Struktur } \\
\text { Kalimat }\end{array}$ & $\begin{array}{c}\text { Kebera } \\
\text { nian }\end{array}$ & $\begin{array}{l}\text { Kelan } \\
\text { caran }\end{array}$ & Suara & $\begin{array}{l}\text { Jml. } \\
\text { Skor }\end{array}$ \\
\hline 1 & Asiah Amini & 2 & 2 & 2 & 3 & 2 & 2 & 13 \\
\hline 2 & Abdul Holik & 3 & 3 & 2 & 4 & 3 & 3 & 18 \\
\hline 3 & Badra Tamami & 3 & 2 & 2 & 3 & 2 & 3 & 15 \\
\hline 4 & Diki Hermawan & 3 & 3 & 3 & 3 & 3 & 3 & 18 \\
\hline 5 & Indra Karso & 1 & 1 & 1 & 1 & 2 & 2 & 8 \\
\hline 6 & M. Sopyan & 2 & 2 & 2 & 3 & 2 & 3 & 14 \\
\hline 7 & M. Abdul Rojak & 3 & 3 & 3 & 3 & 3 & 3 & 18 \\
\hline 8 & M. Dadang Suhendar & 3 & 3 & 3 & 2 & 2 & 2 & 15 \\
\hline 9 & M. Jauhari AJ. & 3 & 3 & 3 & 4 & 2 & 2 & 17 \\
\hline 10 & Nuraeni & 2 & 2 & 2 & 1 & 2 & 2 & 11 \\
\hline 11 & Nurlaela & 3 & 3 & 2 & 2 & 3 & 3 & 16 \\
\hline 12 & Nadiya & 4 & 3 & 3 & 3 & 2 & 2 & 17 \\
\hline 13 & Putri Aprilianti & 3 & 3 & 3 & 2 & 3 & 3 & 17 \\
\hline 14 & Popi Hikmah F. & 3 & 3 & 2 & 3 & 3 & 2 & 16 \\
\hline 15 & Riki Firdaus & 3 & 3 & 3 & 3 & 2 & 3 & 17 \\
\hline 16 & Rouf Firmansyah & 4 & 3 & 2 & 2 & 3 & 3 & 17 \\
\hline 17 & Sunardi & 4 & 3 & 3 & 3 & 2 & 3 & 18 \\
\hline 18 & Sarmidi & 3 & 3 & 3 & 3 & 3 & 3 & 18 \\
\hline 19 & Suheni & 4 & 3 & 2 & 3 & 3 & 3 & 18 \\
\hline 20 & Siti Diana & 2 & 2 & 2 & 2 & 1 & 2 & 11 \\
\hline 21 & Siti Hikmah & 3 & 3 & 3 & 3 & 2 & 2 & 16 \\
\hline 22 & Siti Rosidah & 3 & 2 & 3 & 3 & 3 & 2 & 17 \\
\hline 23 & Saudatul Faridah & 2 & 2 & 2 & 3 & 2 & 1 & 12 \\
\hline 24 & Azizah & 3 & 2 & 3 & 3 & 2 & 3 & 16 \\
\hline 25 & Julaeha & 3 & 3 & 2 & 3 & 2 & 2 & 13 \\
\hline 26 & Dila Andrianti & 3 & 2 & 3 & 1 & 2 & 2 & 13 \\
\hline 27 & Suminah & 2 & $\overline{1}$ & 1 & 2 & 1 & 2 & 9 \\
\hline 28 & Rohanah & 3 & 1 & 2 & 2 & 2 & 3 & 13 \\
\hline 29 & Irwansyah & 3 & 2 & 3 & 3 & 3 & 3 & 17 \\
\hline Jumlah & & 83 & 61 & 70 & 76 & 67 & 81 & 438 \\
\hline \multicolumn{2}{|c|}{ Rata-rata } & 2,86 & 2,10 & 2,41 & 2,62 & 2,31 & 2,82 & 15,10 \\
\hline
\end{tabular}

c. Analisis dan Refleksi Siklus I

Analisis dan refleksi ini dilakukan setelah pembelajaran berlangsung kemudian bersamasama dengan rekan observasi berdiskusi tentang isi pembelajaran yang baru saja. Berdasarkan hasil pengamatan pada tampilan kegiatan belajar mengajar pada siklus kesatu, ada beberapa catatan hasil diskusi yaitu :

1) Situasi kelas belum terkoordinasi dengan baik, hal ini terlihat pada saat proses pembelajaran berlangsung ada siswa yang asyik ngobrol dengan teman sebangkunya, ketika siswa yang lain sudah selesai mengerjakan dan dikumpulkan. Sementara siswa tersebut masih belum selesai dan akhirnya ia menangis karena malu oleh teman-temannya. Supaya siswa lebih fokus dalam 
belajar, maka guru lebih baik menyampaikan dulu tujuan yang ingin dicapai dalam pembelajaran tersebut.

2) Dalam pelaksanaan bercerita di depan kelas, masih banyak siswa yang kesulitan untuk bercerita, mereka minta dibimbing untuk bercerita kata demi kata menjadi kalimat yang sederhana, diterjemahkan dari bahasa Sunda ke Bahasa Indonesia, hal ini sudah biasa dilakukan di kelas IV karena mereka tidak bisa Bahasa Indonesia dengan lancar.

3) Keberanian siswa ketika ada di depan kelas masih kurang sehingga mempengaruhi pemikiran aspek kebahasaan yang lain, seperti lapal dan intonasi, suara terdengar pelan, ini karena merasa ragu dan takut salah.

Dari ketiga hal diatas perlu mendapat perhatian pada siklus berikutnya, bertujuan agar kemampuan berbicara siswa lebih optimal dan siswa lebih sering mengikuti pelajaran berbicara.

\section{Pelaksanaa Tindakan Siklus Kedua}

a. Tujuan

Tujuan dari pelaksanaan tindakan kedua adalah untuk meningkatkan kemampuan berbicara siswa lebih optimal dan siswanya lebih aktif mengikuti pembelajaran berbicara agar memperoleh hasil yang memuaskan.

b. Perencanaan

Pada kegiatan perencanaan pembelajaran siklus II ini dengan memperhatikan pembelajaran siklus I. Adapun perencanaannya sebagai berikut : Pertama, melalui diskusi dengan rekan observasi maksudnya untuk menentukan/memilih jenis gambar tunggal dengan tema bebas. Kedua, menyusun rencana pembelajaran. Ketiga, menetapkan fokus yang akan menjadi perhatian utama masih tentang keberanian, penguasaan kosa kata, struktur kalimat, lapal dan intonasi, serta Keempat, mempersiapkan lembar observasi yang sama dengan pelaksanaan tindakan kelas IV. Rencana pembelajaran pada siklus II, terdiri dari dua kali pertemuan dengan alokasi waktu tiap pertemuan $2 \mathrm{x}$ 35 menit. Pelaksanaan Tindakan dan Observasi

Pada siklus II ini pembelajaran dilaksanakan secara berkelompok maksudnya agar suasananya lebih menyenangkan. Dari jumlah siswa 29 orang tersebut dibagi menjadi enam kelompok, lima kelompok terdiri dari lima orang dan satu kelompok terdiri dari 4 orang. Langkah pertama dalam pembelajaran guru membuka pelajaran, lalu menjelaskan langkah-langkah dasar dalam bercerita, juga menjelaskan hal-hal yang harus diperhatikan dalam menggunakan media gambar.

Langkah selanjutnya siswa berkumpul di kelompok masing-masing dan setiap kelompok mempunyai nama, siswa sendiri yang memilih nama seperti : Kelompok Melati, Kelompok Mawar, Kelompok Kelinci, Kelompok Singa, Kelompok Mangga, Kelompok Jeruk. Mereka kelihatannya sangat senang sekali dengan sistem pembelajaran seperti ini, setelah usai pemberian nama tiap-tiap kelompok mereka bertepuk tangan bersama-sama.

Setelah situsi tertib kemudian guru membagikan gambar tunggal yang berbeda tiap kelompok untuk diamati dan diceritakan isinya. Kemudian guru menjelaskan kegiatan yang harus dilaksanakan siswa dengan gambarnya. Kemudian guru menyampaikan tujuan yang ingin dicapai dilanjutkan dengan membagikan gambar tunggal yang berbeda kepada masing-masing kelompok untuk diamati dan diceritakan isinya.

Enam kelompok belajar tersebut seluruh siswanya mempunyai gambar tunggal yang berbeda hanya formasi dudukannya yang dikelompokkan, situasi setiap kelompok cukup sibuk dan ramai, membandingkan gambar dengan kelompok lain, menyamakan gambar dengan teman sekelompoknya, tapi mereka berkomunikasinya menggunakan bahasa sehari-hari (bahasa Sunda). Ada salah satu kelompok bertanya karena kurang paham dan guru kembali menjelaskan sambil membimbing perbendaharaan kosa kata Bahasa Indonesia.

Ketika guru meminta siswa untuk maju ke depan, mereka masih ragu-ragu persis sama pada pertemuan siklus I, karena belum ada yang mau ke depan, maka guru memberi contoh kembali cara menceritakan gambar, sambil guru memperlihatkan kepada siswa gambar yang akan 
diceritakan, setelah selesai bercerita guru langsung memberikan penguatan bahwa jangan malumalu untuk bercerita dan harus ingat dengan kata kunci "Kita Harus Bisa !". Tapi rupanya waktu untuk pertemuan kesatu ini sudah habis sehingga guru menyuruh siswa untuk beristirahat dulu, selama +10 menit dan akan dilanjutkan pada pertemuan kedua.

Pada pertemuan kedua guru langsung menyuruh siswa untuk maju ke depan, perwakilan dari setiap kelompok secara bergantian maju ke depan, ternyata saat bercerita di depan mereka cukup lancar, cukup berani dengan lapal dan intonasi jelas. Ada permintaan dari masing-masing kelompok untuk membacakan cerita perkelompok ke depan. Dan dipersilahkan mereka itu untuk membacakan cerita secara bersama-sama perkelompok, mereka sangat senang sekali. Sementara itu guru memberikan nilai pada lembaran observasi penilaian keterampilan berbicara. Sambil sesekali membantu atau meneruskan kalimat siswa yang sedang bercerita.

Setelah semua kelompok selesai bercerita di depan kelas, guru dan siswa membahas hasil pada siklus kedua. Disini guru juga tetap memberikan motivasi kepada siswa agar lebih berani dan memberikan penjelasan kembali tentang cara bercerita yang baik di depan kelas. Pada akhir pertemuan kedua diperoleh hasil penilaian keterampilan berbicara sebagai berikut:

1) Siswa yang sudah hampir lancar berbicara dengan penggunaan lapal dan intonasi yang cukup baik, juga memiliki keberanian dengan suara yang cukup keras sebanyaknya 10 orang atau sekitar 34,48\%.

2) Siswa yang cukup lancar dengan lapal dan intonasi cukup seperti membaca, tapi cukup berani sebanyak 14 orang atau sekitar $48,27 \%$.

3) Siswa yang sudah bisa berbicara dengan bimbingan guru, serta suara pelan sebanyak 9 orang atau sekitar 31,03\%.

Observasi kemampuan berbicara siswa dapat dilihat pada tabel 3 sedangkan skor kemampuan berbicara siswa pada siklus II dapat dilihat pada tabel 4 .

Tabel 3.

Observasi Kemampuan Berbicara Siswa Siklus II

\begin{tabular}{|c|c|c|}
\hline No & Nama & Deskripsi Kemampuan \\
\hline 1 & Asiah Amini & Kurang lancar, lapal dan intonasi cukup, kurang berani. \\
\hline 2 & Abdul Holik & Hampir lancar, lapal dan intonasi cukup, cukup berani. \\
\hline 3 & Badra Tamami & Cukup lancar, lapal dan intonasi cukup, cukup berani. \\
\hline 4 & Diki Hermawan & Hampir lancar, lapal dan intonasi cukup, cukup lancar. \\
\hline 5 & Indra Karso & Tidak lancar, tidak berani. \\
\hline 6 & M. Sopyan & Cukup lancar, lapal dan intonasi cukup, kurang berani. \\
\hline 7 & M. Abdul Rojak & Hampir lancar, lapal dan intonasi cukup, cukup berani. \\
\hline 8 & M. Dadang Suhendar & Cukup lancar, lapal dan intonasi cukup, cukup berani. \\
\hline 9 & M. Jauhari AJ. & Hampir lancar, lapal dan intonasi cukup, cukup berani. \\
\hline 10 & Nuraeni & Kurang lancar, lapal dan intonasi cukup, tidak berani. \\
\hline 11 & Nurlaela & Cukup lancar, lapal dan intonasi cukup, cukup berani. \\
\hline 12 & Nadiya & Hampir lancar, lapal dan intonasi cukup, cukup berani. \\
\hline 13 & Putri Aprilianti & Hampir lancar, lapal dan intonasi cukup, cukup berani. \\
\hline 14 & Popi Hikmah F. & Hampir lancar, lapal dan intonasi cukup, cukup berani. \\
\hline 15 & Riki Firdaus & Hampir lancar, lapal dan intonasi cukup, cukup berani. \\
\hline 16 & Rouf Firmansyah & Hampir lancar, lapal dan intonasi cukup, cukup berani. \\
\hline 17 & Sunardi & Hampir lancar, lapal dan intonasi cukup, cukup berani. \\
\hline 18 & Sarmidi & Cukup lancar, lapal dan intonasi cukup, cukup berani. \\
\hline 19 & Suheni & Hampir lancar, lapal dan intonasi cukup, cukup berani. \\
\hline 20 & Siti Diana & Kurang lancar, lapal dan intonasi cukup, tidak berani. \\
\hline 21 & Siti Hikmah & Cukup lancar, lapal dan intonasi cukup, cukup berani. \\
\hline 22 & Siti Rosidah & Cukup lancar, lapal dan intonasi cukup, cukup berani. \\
\hline 23 & Saudatul Faridah & Kurang lancar, lapal dan intonasi cukup, tidak berani. \\
\hline 24 & Azizah & Cukup lancar, lapal dan intonasi cukup, cukup berani. \\
\hline 25 & Julaeha & Cukup lancar, lapal dan intonasi cukup, cukup berani. \\
\hline 26 & Dila Andrianti & Kurang lancar, lapal dan intonasi cukup, tidak berani. \\
\hline 27 & Suminah & Tidak lancar, tidak berani. \\
\hline 28 & Rohanah & Tidak lancar, lapal dan intonasi kurang, tidak berani. \\
\hline
\end{tabular}




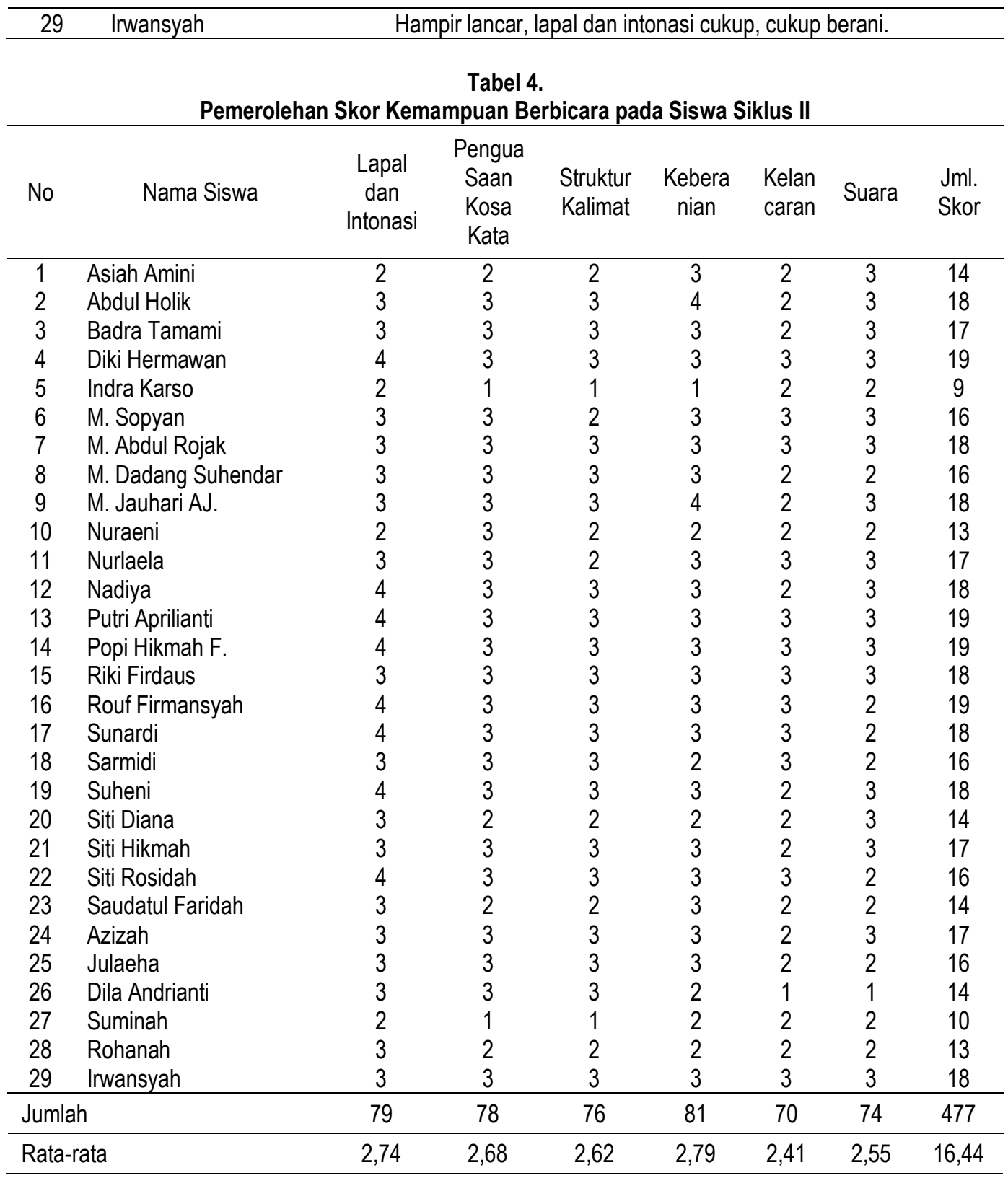

\section{c. Analisis dan Refleksi Siklus II}

Berdasarkan pengamatan terhadap pelaksanaan tindakan pada siklus II dapat dianalisis beberapa data yang layak untuk diperhatikan, antara lain: Pertama, siswa kelas IV sangat senang belajar dengan menggunakan media gambar yang dapat mengungkapkan berbagai cerita walaupun dalam segi kebahasaan siswa kelas IV sangat terbatas tapi yang terpenting adalah siswa merasa senang dengan gambar apalagi bila gambar tersebut kaya akan warna. Kedua, penentuan dan pemilihan gambar sangat menentukan keberhasilan siswa, misalnya gambar yang sederhana dan mudah dipahami siswa sehingga siswa dapat membaca gambar, mengamati dan mengkomunikasikan (bercerita). Ketiga, pemberian penguatan atau gagasan yang akan lebih memotivasi semangat belajar siswa.

\section{Pelaksanaan Tindakan Siklus Ketiga}

Tujuan dari pelaksanaan tindakan ketiga adalah untuk lebih meningkatkan kemampuan siswa dalam berbicara (bercerita) dengan menggunakan media gambar.

a. Perencanaan

Rancangan pengajaran terdiri dari dua kali pertemuan, dengan alokasi waktu tiap pertemuan 2x35 menit. Rencana kegiatan pada siklus IV ini adalah sebagai berikut: 1) Guru membuat media 
gambar sendiri dengan sejumlah siswa 29 orang dan tentunya gambar tersebut yang mudah dipahami oleh siswa kelas IV serta bermacam-macam jenisnya, seperti alat permainan, kendaraan, hewan, buga, benda-benda langit dan lain-lain. 2) Gambar yang dipilih siswa dapat diketahui dengan jelas. Pengamatan sebagai bahan motivasi akan lebih ditampakkan pada siklus ini. 3) Mengadakan observasi / penilaian akhir pada kemampuan berbicara siswa di kelas tanpa menggunakan alat bantu/media sebagai tolak ukur keberhasilan penggunaan media gambar dalam meningkatkan kemampuan berbicara.

b. Pelaksanaan Tindakan dan Observasi

Pada siklus III ini guru memfokuskan pembelajaran pada keterampilan berbicara secara individual tetapi formasi duduk masih tetap berkelompok. Setelah guru menyampaikan tujuan yang ingin dicapai, kemudian guru mengeluarkan berbagai jenis potongan gambar, sebanyak 29 buah gambar. Gambar tersebut diletakkan di atas meja guru, kemudian siswa disuruh ke depan (agar situasi pembelajaran tetap kondusif maka siswa untuk maju ke depan secara perkelompok.

Semua siswa ribut memilih gambar, mereka saling berebut tetapi mereka tampak senang. Setelah masing-masing mendapatkan gambar mereka kembali duduk dan mengamati gambar itu dengan asyik. Mereka saling bertukar pikiran dengan teman-teman sekelompoknya, suasana kelas cukup ramai, selain siswa mereka-reka cerita gambar dengan suara yang cukup keras juga diselang siswa yang bertanya kepada guru tentang bercerita dengan bantuan gambar.

Waktu sudah menunjukan pukul 08.00, siswa masih asyik dengan gambarnya. Ketika guru meminta siswa yang mau ke depan dengan serempak siswa menjawab "saya" sambil menunjukan jari tangan kanan, ternyata mereka sangat bersemangat sekali. Ketika dipersilahkan ke depan salah satu siswa maju ke depan, saat siswa mulai bercerita tanpa gambar, teman-temannya mendengarkan dengan seksama dan mereka bertepuk tangan ketika ceritanya selesai, walaupun cerita tersebut hanya beberapa kalimat saja yang diungkapkannya. Pada pertemuan pertama ini guru dan siswa membahas penampilan tiap siswa yang bercerita di depan kelas, tentang kelebihan dan kelemahannya. Kelemahannya rata-rata pada suara yang kurang keras. Guru kembali mengingatkan cara berbicara yang baik. Pertemuan satu waktunya sudah habis dilanjutkan dengan pertemuan kedua.

Pada pertemuan kedua ini, siswa melanjutkan kegiatan bercerita secara bergiliran di depan kelas dengan tema sesuai dengan gambar yang diambilnya, misalnya siswa mengambil gambar matahari berarti ia akan bercerita tentang matahari, tapi siswa bukan menceritakan isi gambar tetapi siswa bercerita tanpa gambar. Guru mengamati siswa dan memberikan penilaian tentang kedua aspek, yaitu aspek kebahasan dan aspek non kebahasan. Pada setiap siswa selesai bercerita tanpa gambar, guru memberikan tanggapan berupa ulasan dan motivasi berupa pujian serta tepuk tangan dari teman-temannya. Di akhir pelajaran guru memberikan penguatan dan pengayaan tentang cerita yang disampaikan oleh semua siswa secara garis besar. berikut:

Pada akhir siklus III ini diperoleh hasil-hasil pengamatan atau penilaian dengan rinci sebagai

1) Siswa yang sudah lancar menggunakan lafal dan intonasi yang baik, memiliki keberanian yang cukup dan dengan suara yang cukup sebanyak 15 orang atau sekitar $51,72 \%$.

2) Siswa yang cukup lancar, berani, suara cukup, serta lafal dan intonasi yang cukup sebanyak 10 orang atau sekitar $34,48 \%$.

3) Siswa yang belum lancar tetapi sudah berani dengan suara yang cukup sebanyak 4 orang atau sekitar $13,79 \%$.

Observasi kemampuan berbicara siswa dapat dilihat pada tabel 5 sedangkan skor kemampuan berbicara siswa pada siklus II dapat dilihat pada tabel 6 . 
Tabel 5.

Observasi Kemampuan Berbicara Siswa Siklus 3

\begin{tabular}{|c|c|c|}
\hline No & Nama & Deskripsi Kemampuan \\
\hline 1 & Asiah Amini & Cukup lancar, lapal dan intonasi cukup, cukup berani. \\
\hline 2 & Abdul Holik & Hampir lancar, lapal dan intonasi cukup, cukup berani. \\
\hline 3 & Badra Tamami & Hampir lancar, lapal dan intonasi cukup, cukup berani. \\
\hline 4 & Diki Hermawan & Hampir lancar, lapal dan intonasi cukup, cukup berani. \\
\hline 5 & Indra Karso & Tidak lancar, lapal dan intonasi kurang, tidak berani. \\
\hline 6 & M. Sopyan & Cukup lancar, lapal dan intonasi cukup, cukup berani. \\
\hline 7 & M. Abdul Rojak & Hampir lancar, lapal dan intonasi cukup, cukup berani. \\
\hline 8 & M. Dadang Suhendar & Hampir lancar, lapal dan intonasi cukup, cukup berani. \\
\hline 9 & M. Jauhari AJ. & Hampir lancar, lapal dan intonasi cukup, cukup berani. \\
\hline 10 & Nuraeni & Cukup lancar, lapal dan intonasi cukup, cukup berani. \\
\hline 11 & Nurlaela & Hampir lancar, lapal dan intonasi cukup, cukup berani. \\
\hline 12 & Nadiya & Hampir lancar, lapal dan intonasi cukup, cukup berani. \\
\hline 13 & Putri Aprilianti & Hampir lancar, lapal dan intonasi cukup, cukup berani. \\
\hline 14 & Popi Hikmah F. & Hampir lancar, lapal dan intonasi cukup, cukup berani. \\
\hline 15 & Riki Firdaus & Hampir lancar, lapal dan intonasi cukup, cukup berani. \\
\hline 16 & Rouf Firmansyah & Hampir lancar, lapal dan intonasi cukup, cukup berani. \\
\hline 17 & Sunardi & Hampir lancar, lapal dan intonasi cukup, cukup berani. \\
\hline 18 & Sarmidi & Cukup lancar, lapal dan intonasi cukup, kurang berani. \\
\hline 19 & Suheni & Hampir lancar, lapal dan intonasi cukup, cukup berani. \\
\hline 20 & Siti Diana & Cukup lancar, lapal dan intonasi cukup, kurang berani. \\
\hline 21 & Siti Hikmah & Hampir lancar, lapal dan intonasi cukup, cukup berani. \\
\hline 22 & Siti Rosidah & Hampir lancar, lapal dan intonasi cukup, cukup berani. \\
\hline 23 & Saudatul Faridah & Cukup lancar, lapal dan intonasi cukup, cukup berani. \\
\hline 24 & Azizah & Hampir lancar, lapal dan intonasi cukup, cukup berani. \\
\hline 25 & Julaeha & Cukup lancar, lapal dan intonasi cukup, cukup berani. \\
\hline 26 & Dila Andrianti & Tidak lancar, lapal dan intonasi kurang, tidak berani. \\
\hline 27 & Suminah & Tidak lancar, lapal dan intonasi kurang, tidak berani. \\
\hline 28 & Rohanah & Tidak lancar, lapal dan intonasi kurang, tidak berani. \\
\hline 29 & Irwansyah & Hampir lancar, lapal dan intonasi cukup, cukup berani. \\
\hline
\end{tabular}

Tabel 6.

Pemerolehan Skor Kemampuan Berbicara pada Siswa Siklus III

\begin{tabular}{llccccccc}
\hline No & \multicolumn{1}{c}{ Nama Siswa } & $\begin{array}{c}\text { Lapal } \\
\text { dan } \\
\text { Intonasi }\end{array}$ & $\begin{array}{c}\text { Pengua } \\
\text { saan } \\
\text { Kosa } \\
\text { Kata }\end{array}$ & $\begin{array}{c}\text { Struktur } \\
\text { Kalimat }\end{array}$ & $\begin{array}{c}\text { Kebera } \\
\text { nian }\end{array}$ & $\begin{array}{c}\text { Kelan } \\
\text { caran }\end{array}$ & Suara & $\begin{array}{c}\text { Jml. } \\
\text { Skor }\end{array}$ \\
\hline 1 & Asiah Amini & 2 & 3 & 2 & 3 & 2 & 3 & 15 \\
2 & Abdul Holik & 4 & 3 & 3 & 4 & 3 & 3 & 20 \\
3 & Badra Tamami & 4 & 3 & 2 & 3 & 3 & 3 & 18 \\
4 & Diki Hermawan & 4 & 3 & 3 & 3 & 3 & 3 & 19 \\
5 & Indra Karso & 2 & 2 & 2 & 1 & 2 & 2 & 13 \\
6 & M. Sopyan & 3 & 3 & 2 & 3 & 3 & 3 & 17 \\
7 & M. Abdul Rojak & 3 & 3 & 3 & 3 & 3 & 3 & 18 \\
8 & M. Dadang Suhendar & 4 & 3 & 3 & 3 & 3 & 2 & 18 \\
9 & M. Jauhari AJ. & 3 & 3 & 3 & 4 & 3 & 3 & 19 \\
10 & Nuraeni & 3 & 3 & 2 & 2 & 2 & 3 & 15 \\
11 & Nurlaela & 4 & 3 & 3 & 3 & 3 & 3 & 19 \\
12 & Nadiya & 4 & 3 & 3 & 3 & 3 & 4 & 20 \\
13 & Putri Aprilianti & 4 & 3 & 3 & 3 & 3 & 3 & 19 \\
14 & Popi Hikmah F. & 4 & 3 & 3 & 3 & 3 & 3 & 19 \\
15 & Riki Firdaus & 3 & 3 & 3 & 3 & 3 & 3 & 18 \\
16 & Rouf Firmansyah & 4 & 3 & 3 & 4 & 3 & 3 & 20 \\
17 & Sunardi & 4 & 3 & 3 & 3 & 3 & 3 & 19 \\
18 & Sarmidi & 3 & 3 & 3 & 3 & 3 & 2 & 17 \\
19 & Suheni & 4 & 3 & 3 & 3 & 3 & 3 & 19 \\
20 & Siti Diana & 3 & 3 & 2 & 2 & 2 & 3 & 15 \\
\hline
\end{tabular}




\begin{tabular}{|c|c|c|c|c|c|c|c|c|}
\hline 21 & Siti Hikmah & 3 & 3 & 3 & 3 & 3 & 3 & 18 \\
\hline 22 & Siti Rosidah & 4 & 3 & 3 & 3 & 3 & 3 & 19 \\
\hline 23 & Saudatul Faridah & 3 & 3 & 2 & 3 & 2 & 2 & 15 \\
\hline 24 & Azizah & 4 & 3 & 3 & 3 & 3 & 3 & 19 \\
\hline 25 & Julaeha & 3 & 3 & 3 & 3 & 3 & 2 & 17 \\
\hline 26 & Dila Andrianti & 3 & 3 & 3 & 2 & 1 & 1 & 14 \\
\hline 27 & Suminah & 3 & 2 & 2 & 1 & 1 & 2 & 11 \\
\hline 28 & Rohanah & 3 & 3 & 2 & 1 & 2 & 3 & 14 \\
\hline 29 & Irwansyah & 4 & 3 & 3 & 3 & 3 & 3 & 19 \\
\hline \multicolumn{2}{|c|}{ Jumlah } & 96 & 85 & 78 & 81 & 77 & 81 & 501 \\
\hline \multicolumn{2}{|c|}{ Rata-rata } & 3,31 & 2,93 & 2,68 & 2,79 & 2,65 & 2,79 & 17,27 \\
\hline
\end{tabular}

Berdasarkan tabel 5 dan tabel 6 dapat disimpulkan bahwa hasil pembelajaran Bahasa Indonesia dengan menggunakan media gambar mengalami peningkatan dan kemampuan berbicara, dari 3 orang siswa yang mampu berbicara dengan menggunakan gambar meningkat menjadi 15 orang siswa yang mampu bercerita dengan menggunakan gambar. Kini hampir semua siswa kelas IV SD Negeri 2 Sukamaju Kecamatan Indihiang Kota Tasikmalaya Kota Tasikmalaya dapat bercerita sederhana meskipun tanpa gambar dan tentunya mereka tahu tema apa yang akan mereka ceritakan.

c. Analisis dan Refleksi Siklus III

Berdasarkan hasil dan proses pembelajaran pada siklus III ini, dapat menganalisis beberapa hal penting untuk diperhatikan antara lain :

1) Ternyata bila guru menyediakan potongan gambar untuk diceritakan dan pemilihannya diserahkan kepada siswa, ternyata siswa lebih senang dan semangat dan itu membantu siswa dalam kelancaran bercerita.

2) Motivasi yang diberikan guru secara terus menerus dan pemberian penguatan berupa pujian mendorong siswa menjadi giat belajar.

3) Faktor keberanian dalam bercerita adalah penentu kelancaran disamping penguasaan kosa kata yang harus cukup banyak.

Pada siklus III ini kegiatan pelaksanaan tindakan sudah cukup berhasil, karena sebagian siswa sudah cukup lancar bercerita sesuai dengan tujuan yang ingin dicapai, sehingga dengan bantuan media gambar siswa mampu meningkatkan hasil belajar secara signifikan, sudah menunjukkan adanya perbaikan-perbaikan dalam menuangkan bahasa lisan yaitu bercerita.

\section{Deskripsi Pendapat Siswa dan Guru}

a. Deskripsi Pendapat Siswa

Pendapat siswa tentang pelaksanaan tindakan yang dilakukan mengajukan beberapa pertanyaan yang berhubungan dengan: 1) kesan siswa ketika mengikuti proses pembelajaran keterampilan berbicara dengan menggunakan media gambar, 2) kesan siswa tentang perbandingan ketika harus bercerita di depan kelas dengan bantuan gambar dan dengan tanpa bantuan gambar atau tidak melihat gambar hanya ditentukan temanya saja. 3) Hambatan atau kesulitan siswa ketika pembelajaran keterampilan berbicara langsung

Berdasarkan hal-hal tersebut di atas, maka penulis mendapatkan jawaban sebagai berikut:

1) Hampir semua siswa merasa senang ketika mengikuti pembelajaran selama penelitian ini.

2) Hampir semua siswa memilih bercerita dengan bantuan gambar, karena gambar bisa memberikan ide untuk diceritakan tetapi bila langsung disuruh bercerita tanpa gambar mereka menjawab merasa kesulitan.

3) Kesulitan mereka rasakan pada saat akan memulai cerita, untuk itu mereka harus dibantu dulu dengan pertanyaan guru. Dan yang paling dirasakan kesulitannya adalah dalam permasalahan penggunaan Bahasa Indonesia dalam bercerita, untuk itu mereka memilih mendaftarkan dulu kosa kata yang tampak dalam gambar untuk kemudian mereka rangkai menjadi kalimat demi kalimat. 
b. Deskripsi Pendapat Guru

Dalam mendeskripsikan pendapat guru ini adalah guru yang menjadi partner penulis dalam penelitian ini, yaitu mereka yang menjadi observer. Beberapa pendapat tersebut adalah:

1) Penggunaan gambar sebagai alat bantú dalam pembelajaran berbicara adalah salah satu alternatif yang layak dicoba oleh guru-guru yang lain.

2) Gambar adalah alat bantu yang yang disukai anak terutama siswa Sekolah Dasar dan dengan gambar para siswa akan merasa bermain sambil belajar.

3) Penguasaan Bahasa Indonesia nampaknya harus diprioritaskan sebelum pembelajaran keterampilan berbicara meskipun menggunakan media pembelajaran seperti gambar.

4) Guru harus panda-pandai memilih gambar apa dan bagaimana yang cocok dengan usia kelas yang diajarnya.

5) Gambar bukan satu-satunya media yang bisa membantu kemampuan berbicara siswa, tapi langkah baiknya apabila guru yang lain mencoba menggunakan media gambar baik dalam pembelajaran keterampilan berbicara maupun keterampilan menulis.

Berdasarkan temuan penelitian pada siklus ketiga diperoleh hasil yang sangat memuaskan, dari 29 siswa yang mampu berbicara dengan menggunakan media gambar mencapai 15 orang siswa atau sekitar $51,72 \%$. Penggunaan gambar yang bervariasi, baik dalam bentuk gambar seri atau gambar tunggal maupun cara menentukan dan pemilihannya, membuat pembelajaran menjadi lebih menyenangkan tidak membosankan, serta pemilihan gambar itu harus disesuikan dengan tujuan yang handak dicapai.

Kegiatan penelitian tindakan yang melalui tiga siklus ini mendapatkan hasil yang cukup memuaskan, dari yang asalnya siswa didak bisa bercerita menjadi lancar dan berani untuk bercerita. Kini hampir semua siswa kelas IV dapat bercerita sederhana meskipu tanpa gambar, dan tentunya tahu tema apa yang akan diceritakan. Hal ini sejalan dengan hasil penelitian Pratiwi, et.al (2013), Putra (2014) dan Aprinawati (2017). Berdasarkan hasil pengolahan data peneliitian yang telah dilakukan dapat dikatakan pembelajaran Bahasa Indonesia dengan menggunakan media gambar dapat meningkatkan kemampuan berbicara siswa.

\section{KESIMPULAN}

Pembelajaran berbicara dengan menggunakan media gambar mendapatkan hasil yang cukup memuaskan, dari yang asalnya tidak bisa berbicara menjadi lebih lancar dan berani untuk bercerita. Kini hampir hampir semua siswa dapat bercerita meskipun dengan gambar yang tentunya tahu tema apa yang akan diceritakan, ini terlihat dari 29 orang siswa pada pre-test pendahuluan sebanyak 3 orang saja yang dapat berbicara dengan cukup lancar dan memiliki keberanian yang cukup sekitar $10.34 \%$. Kegiatan siklus I ada peningkatan sebanyak 6 orang siswa yang termasuk kategori hampir lancar dan hampir berani dengan secara cukup atau sekitar 20,68 \%. Pada kegiatan siklus II adanya peningkatan yang cukup sebanyak 10 orang siswa yang termasuk kategori hampir lancar dan berani dengan cuara cukup jelas atau sekitar $34,48 \%$. Selanjutnya pada siklus III mencapai 15 orang siswa yang termasuk kategori baik sekitar 51,72 \%, 10 orang siswa yang termasuk kategori cukup sekitar $34,48 \%$ dan 4 orang siswa yang masih dalam kategori kurang sekitar $13,79 \%$. Dan keseluruhan peralihan adanya peningkatan keberhasilan awalnya dari 10,34 meningkat mrnjadi $51,72 \%$.

Berdasarkan temuan dan pembahasan hasil penelitian dapat disimpulkan bahwa pembelajaran Bahasa Indonesia dengan menggunakan media gambar dapat meningkatkan kemampuan berbicara siswa kelas IV SD Negeri 2 Sukamaju Kota Tasikmalaya pada tahun pelajaran 2019/2020 


\section{REKOMENDASI}

berikut:

Berdasarkan penelitian yang telah dilakukan rekomendari yang diberikan adalah sebagai

1. Pembelajaran Bahasa Indonesia terutama di kelas rendah sebaiknya menggunakan alat bantu seperti gambar karena mampu meningkatkan kemampuan berbicara siswa.

2. Siswa senang dan antusias ketika kemampuan berbicara mereka dibantu dengan gambar yang mereka pilih sendiri, maka biarkan mereka memilih dan menentukan sendiri jenis gambar yang akan mereka ceritakan asal tidak lepas dari tema yang akan dibahas dalam pembelajaran, apalagi siswa kelas rendah paling suka akan bentuk dan warna.

3. Penggunaan media gambar dapat membantu pembelajaran keterampilan berbicara, juga dapat digunakan dalam keterampilan berbahasa lainnya, seperti keterampilan membaca, menulis dan menyimak.

\section{UCAPAN TERIMAKASIH}

Ucapan terimakasih disampaikan kepada Kepala Sekolah SD Negeri 2 Sukamaju Kota Tasikmalaya beserta rekan-rekan sejawat guru yang telah memberikan izin, dukungan dan bantuan kepada peneliti selama melaksanakan penelitian ini.

\section{DAFTAR PUSTAKA}

Aprinawati, I. (2017). Penggunaan Media Gambar Seri Untuk Meningkatkan Kemampuan Berbicara Anak Usia Dini. Jurnal Obsesi Vol 1 (1).

Arsyad, A. (2007). Media Pembelajaran. Jakarta: Raja Grofindo Persada.

Ibda, H dan Ahmadi, F. 2018. Media Literasi Sekolah (Teori dan Praktik). Semarang: CV. Pilar Nusantara.

Kemmis, S and McTaggart, R. (1988). The Action Research Planner. Deakin University

Pratiwi, et.al. (2013). Peningkatan Kemampuan Berbicara Dengan Menggunakan Media Gambar Berseri Pada Pembelajaran Bahasa Indonesia Kelas I SD. Jurnal Khatulistiwa. Vol 2(12).

Putra, N.A. (2014). Penggunaan Media Gambar Seri untuk Meningkatkan Keterampilan Menulis Narasi pada Mata Pelajaran Bahasa Indonesia Siswa Kelas IV SDN Moahino Kabupaten Morowali. Jurnal Kreatif Online Vol 2 (4).

Setyonegoro, A. (2013). Hakikat, Alasan, Dan Tujuan Berbicara (Dasar Pembangun Kemampuan Berbicara Mahasiswa). Jurnal: Pena. Volume 3 Nomor 1.

Suyanto, et. al. (2017). Perbandingan Hasil Belajar Siswa Menggunakan Media Gambar Bergerak Dengan Gambar Diam. Jurnal Pembelajaran Fisika. Volume 5 Nomor 3.

Tarigan, D. 1997. Pengembangan Keterampilan Berbicara. Jakarta: Depdikbud. Undang-undang Republik Indonesia No. 20 Tahun 2003 tentang Sistem Pendidikan Nasional. 
Jurnal Wahana Pendidikan, 8(1), 27-42, Januari 2021

P-ISSN: 2355-2425 dan E-ISSN: 2715-6796 